\begin{tabular}{|l|l|l|}
\hline \multicolumn{2}{|c|}{ PublisherInfo } \\
\hline \hline PublisherName & $:$ & BioMed Central \\
\hline \hline PublisherLocation & $:$ & London \\
\hline \hline PublisherImprintName & $:$ & BioMed Central \\
\hline \hline
\end{tabular}

\title{
Histone released on cell death charges
}

\begin{tabular}{|l|l|l||}
\hline \multicolumn{2}{|c|}{ ArticleInfo } \\
\hline \hline ArticleID & $:$ & 4843 \\
\hline \hline ArticleDOI & $:$ & $10.1186 /$ gb-spotlight-20030922-01 \\
\hline \hline ArticleCitationID & $:$ & spotlight-20030922-01 \\
\hline \hline ArticleSequenceNumber & $:$ & 195 \\
\hline \hline ArticleCategory & $:$ & Research news \\
\hline ArticleFirstPage & $:$ & 1 \\
\hline \hline ArticleLastPage & $:$ & 3 \\
\hline \hline & & RegistrationDate : 2003-9-22 \\
\hline ArticleHistory & $:$ & OnlineDate \\
\hline \hline ArticleCopyright & $:$ & BioMed Central Ltd2003-9-22 \\
\hline \hline ArticleGrants & $:$ & \\
\hline \hline ArticleContext & $:$ & 130594411 \\
\hline \hline
\end{tabular}




\section{David Secko}

Email: dmsecko@interchange.ubc.ca

Apoptosis is a highly regulated cell death mechanism employed by organisms to regulate tissue growth, control developmental processes, and eliminate harmful cells. Mitochondria play a central role in apoptosis by releasing molecules (such as cytochrome c) that activate the caspase pathways to lead to cell death. Many proteins have been linked to this mitochondrial release - including p53 and the Bcl-2 family of proteins (e.g., Bcl-2, Bcl-xL, Bax, Bak) that directly modulate outer mitochondrial membrane permeability - but how nuclear DNA damage is linked to the mitochondria during apoptosis has been unclear. In the September 19 Cell, Akimitsu Konishi and colleagues at the Osaka University Medical School report that DNA damage induces the release of histone H1.2, inducing cytochrome c release and leading to apoptosis (Cell 2003, 114:673-688).

Konishi et al. used an in vitro assay that monitored the release of cytochrome $\mathrm{c}$ from isolated rat liver mitochondria. This assay allowed the biochemical purification of cytochrome c, releasing components from X-ray irradiated rat thymus cytosol, and included histone H1.2. The cytochrome c-releasing ability of H1.2 was confirmed with recombinant mouse histone $\mathrm{H} 1.2$ (rH1.2) and shown to be unique, since the other four components $(\mathrm{H} 1.1, \mathrm{H} 1.3-\mathrm{H} 1.5)$ of histone $\mathrm{H} 1$ did not show strong cytochrome c-releasing activity. The authors then irradiated mice lacking H1.2 and showed that H1.2 KO thymocytes were more resistant to X-ray-induced apoptosis than wt thymocytes. In addition, when H1.2 levels were reduced by expression of $\mathrm{H} 1.2$ antisense mRNA, irradiation did not result in cytochrome c release.

The authors then explored how H1.2 caused release of cytochrome c. An examination of known regulators of apoptosis showed that in Bak-deficient mice, H1.2 did not induce cytochrome c release, suggesting that such release was Bak-dependent. p53 was also shown to be necessary, as p53 ${ }^{-/-}$mice did not release H1.2 into the cytosol. Apoptosis induced by exposure to UV or tumor necrosis factor did not require $\mathrm{H} 1.2$, implicating this protein as a specific factor in apoptosis induced by X-rays - the main initiator of which is DNA-double-strand breaks.

"We showed that during DNA double-strand break-induced apoptosis, the linker histone H1.2 is released from the nucleus into the cytoplasm where it triggers [apoptosis]," conclude the authors.

"An emerging theme therefore is that at least some supposedly workaday components of the cell actually play a vital role in monitoring and signaling various forms of damage and abnormalities in partnership with professionals like p53," write David Gillespie and Karen Vousden from the Beatson Institute for Cancer Research in an accompanying preview article. 


\section{References}

1. Apoptosis: letting slip the dogs of war

2. Decision making by p53: life, death and cancer

3. Cell death regulation by the Bcl-2 protein family in the mitochondria

4. Cell, [http://www.cell.com/]

5. Osaka University Medical School, [http://www.med.osaka-u.ac.jp/]

6. Beatson Institute for Cancer Research, [http://www.beatson.gla.ac.uk/]

This PDF file was created after publication. 